\title{
Article \\ Radiological Dose Assessment of the Landfill Disposal of Consumer Products Containing Naturally Occurring Radioactive Materials in South Korea
}

\author{
Mercy Nandutu and Juyoul Kim *(D) \\ Department of NPP Engineering, KEPCO International Nuclear Graduate School, 658-91 Haemaji-ro \\ Seosaeng-myeon, Ulju-gun, Ulsan 45014, Korea; mercynandutu@gmail.com \\ * Correspondence: jykim@kings.ac.kr; Tel.: +82-52-712-7306; Fax: +82-52-712-7375
}

check for updates

Citation: Nandutu, M.; Kim, J. Radiological Dose Assessment of the Landfill Disposal of Consumer Products Containing Naturally Occurring Radioactive Materials in South Korea. Appl. Sci. 2021, 11, 7172. https://doi.org/10.3390/app11157172

Academic Editor: Antonio Insolia

Received: 5 July 2021

Accepted: 30 July 2021

Published: 3 August 2021

Publisher's Note: MDPI stays neutral with regard to jurisdictional claims in published maps and institutional affiliations.

Copyright: (c) 2021 by the authors. Licensee MDPI, Basel, Switzerland. This article is an open access article distributed under the terms and conditions of the Creative Commons Attribution (CC BY) license (https:// creativecommons.org/licenses/by/ $4.0 /)$.
Abstract: Naturally occurring radioactive materials (NORMs) are long-lived radioactive elements such as uranium, thorium, and potassium, and theirdecay products. They are abundant in natural rocks and minerals. In this study, we conducted a radiological dose assessment of the disposal of consumer products (CPs) containing NORMs at landfills and incinerators in South Korea. Household wastes were categorized as combustible and noncombustible on the basis of activity concentrations (ACs) ranging below and above $1 \mathrm{~Bq} / \mathrm{g}$, respectively. Analysis data were obtained from previous literature and the Nuclear Safety and Security Commission (NSSC) of South Korea, and statistical analysis was performed using an interval plot and 95\% confidence interval of mean for each category as an input. Using RESRAD computer codes for noncombustible CPs with AC below and above 1 $\mathrm{Bq} / \mathrm{g}$, we found out that the dose rate was below and above $1 \mathrm{mSv} / \mathrm{y}$, respectively. The RESRADOFFSITE results showed that the dose incurred during the study period for both ranges of AC was all below the public dose limit of $1 \mathrm{mSv} / \mathrm{y}$. NORM and LegacY Site Assessment (NORMALYSA) code was used to validate the result of the RESRAD-ONSITE code, and the results showed that the dose was equal to and above $1 \mathrm{mSv} / \mathrm{y}$ for ACs below and above $1 \mathrm{~Bq} / \mathrm{g}$, respectively. HotSpot code was used for dose evaluation to offsite residents from incineration of combustible CPs, and the resulting dose was below $1 \mathrm{mSv} / \mathrm{y}$. These findings can be used as a guideline for managing public exposure from landfill sites with varying ACs ranges. Therefore, the competent authority should ensure that criteria and protection measures are established for people who live within a distance of $10 \mathrm{~km}$ from incinerators and landfill sites that are contaminated with consumer products containing NORMs.

Keywords: naturally occurring radioactive materials; consumer products; radiological dose assessment; landfill disposal; public exposure; RESRAD; HotSpot; NORMALYSA

\section{Introduction}

Natural radionuclides are found in all minerals and raw materials, the most important of which are radionuclides in the ${ }^{238} \mathrm{U}$ and ${ }^{232} \mathrm{Th}$ decay series, as well as ${ }^{40} \mathrm{~K}$. In most human activities involving minerals and raw materials, exposure to these radionuclides is not significantly higher than normal background levels. However, human activities such as uranium mining can result in significantly high radiation exposures that may require regulation. Naturally occurring radioactive materials (NORMs) [1] cause these increased exposures. There are two ways people can be exposed to NORMs: external exposure, where the source remains outside the body, and internal exposure, where radioactive material is carried into the body through inhalation, ingestion, or absorption. Exposure to NORMs does not have the same acute and severe impacts as exposure to high radiation levels from artificial sources. Chronic NORM exposure exceeding the general public's exposure guidelines or occurring in the absence of proper safety precautions may result in delayed effects such as the development of certain cancers [2]. These NORMs can be found in a variety of applications, ranging from household to industrial applications, and their 
activity concentration (AC) can be increased because of human activities and industrial processes [3]. Consumer products (CPs) containing NORMs are used directly and indirectly in our daily lives and are disposed of in landfills uncontrollably alongside other household wastes. This uncontrolled disposal exposes the public to a significant amount of radiation. In South Korea, some consumer goods (e.g., anion patches, necklaces, latex pillows, and mattresses) are made from raw materials containing NORMs. Some of these products contain a certain amount of radioactivity and may lead to a calculable dose to the user [4].

The International Atomic Energy Agency (IAEA) defines a CP as a device or manufactured item into which radionuclides have been intentionally incorporated or produced by activation or that generates ionizing radiation and can be sold or made available to members of the public without regulatory control after sale. The IAEA regards widespread use of CPs to be beyond effective regulatory control because of the uncontrolled supply to the public and the disposal of these products after usage. The accumulation of such materials at a waste disposal facility may pose a radiological risk and should be subjected to dose assessment to ensure that landfill workers and the public are protected from unjustified radiation exposure [5]. The 10 Code of Federal Regulation 20, "Process for Alternative Disposal" of the U.S. Nuclear Regulatory Commission, highlighted that very low level waste (VLLW) containing some residual radioactivity, such as NORMs, can be safely disposed of in hazardous or municipal solid waste (MSW) landfills to protect people and the environment from the effects of ionizing radiation [6]. These wastes are classified as exempt due to their low ACs of less than $10 \mathrm{~Bq} / \mathrm{g}$. According to the Nuclear Safety and Security Commission (NSSC) Notice No. 2020-6, all exempt wastes can be incinerated, recycled, or disposed in municipal landfills [7]. The Spanish government emphasizes the importance of minimizing the quantities of solid wastes by recycling or reusing those materials whenever possible or reducing the volumes, implying a concentration of activity through compression, incineration, or other methods before the disposal of final wastes into controlled landfills [8]. The 147 guidelines of the European Commission for the regulatory control of $\mathrm{CPs}$ containing radioactive substances categorizes CPs into three categories: existing products, which are currently being manufactured and are readily available for public use; novel products, which require authorization by the competent authority; and historic products, which are currently not being manufactured but can be found in disposal facilities [9].

The growing population and rapid economic growth of South Korea have led to a steady increase in the amount of waste, especially industrial and household wastes. Such wastes may contain NORMs, posing a disposal concern to the public, and dose assessment is required to ensure that the site is safe for public use. In 2017, the total amount of waste generated was 429,531 tons/day, of which $12.5 \%$ and $87.5 \%$ were from industrial and household wastes, respectively. In South Korea, $61.6 \%$ of household wastes are recycled, $24.9 \%$ are incinerated, and approximately $13.5 \%$ are disposed in municipal landfills [10].

Managing MSW properly is a critical aspect of urban public health. However, landfill sustainability is a major concern, as increasing MSW takes up limited landfill space. Therefore, incinerating these wastes and reusing fly ash residues is a solution to reduce the burden on landfill space [11]. Landfills are used to dispose of a variety of garbage, and the level of control increases as the hazard level of waste increases, and they are classified according to the type of disposal and regulatory requirements [12]. Some researchers have used RESidual RADioactive (RESRAD)-ONSITE computer code to estimate environmental risk posed by mine tailing sites [13]. The nuclides in question were ${ }^{40} \mathrm{~K},{ }^{226} \mathrm{Ra},{ }^{232} \mathrm{Th}$, and ${ }^{238} \mathrm{U}$ with very low ACs, resulting in low doses below the public dose limit of $1 \mathrm{mSv} /$ year. RESRAD code has also been used to evaluate the risk of human exposure to NORMs in soil [14]. A radiological impact assessment report must be prepared to comply with the Atomic Energy Licensing Act 1984, Act 304, and the Guidelines LEM/TEK/30 SEM.2, September 1996, for the landfill disposal of NORM wastes in Malaysia. Most of Malaysia's NORM issues are related to tin mining, mineral sand processing, and oil production [15]. Several studies on the disposal of NORMs, technologically enhanced naturally occurring 
radioactive materials (TENORMS), VLLW, and other industrial wastes on landfills have been conducted, as well as studies on the use of RESRAD, HotSpot, and NORM and LegacY Site Assessment (NORMALYSA) codes. However, no study has been performed on the uncontrolled disposal of CPs containing NORMs via landfills and incineration, considering that such materials are used in everyday life and might be disposed of alongside other household wastes, which may result in uncontrolled radiation exposure [16-19]. Similar studies have also been conducted to model radiological doses from sites contaminated with artificial radionuclides such as ${ }^{137} \mathrm{Cs},{ }^{129} \mathrm{I}$, and ${ }^{14} \mathrm{C}[20]$. Several studies have been conducted to assess radiological dose from the use of CPs containing NORMs; however, less attention has been paid to assessing radiological dose from the landfill disposal of $\mathrm{CPs}$ containing NORMs. This study performs a radiological dose assessment from the landfill disposal of CPs containing NORMs to the public in South Korea. This study is critical because understanding the estimation of radiation doses to members of the public living around landfill sites enables the competent authority to determine how the general public can be protected from an uncontrolled radiation exposure.

\section{Materials and Methods}

\subsection{CPs Containing NORMs}

In this study, 225 raw data containing specific ACs of various CPs containing NORMs were obtained from previous literature and the database of Nuclear Safety and Security Commission (NSSC) in South Korea. The data were grouped into two categories on the basis of combustible and noncombustible CPs containing NORMs. To take care of the outliers in data representation, we further them grouped in two categories according to the range of $\mathrm{AC}$ that is below and above $1 \mathrm{~Bq} / \mathrm{g}$. The mean specific activity for various product concentration ranges was obtained and statistically analyzed using an interval plot in Minitab for ${ }^{238} \mathrm{U},{ }^{232} \mathrm{Th}$, and ${ }^{40} \mathrm{~K}$ with a $95 \%$ confidence interval for the mean of each product for different concentration ranges. An assumption was made that, after the incineration of CPs containing NORMs, ash residues are disposed of in landfills, which contributes to a slight increase in the AC of NORM-added CPs at landfill sites. Therefore, the total specific ACs of combustible and noncombustible CPs containing NORMs were used as input data to RESRAD codes in $\mathrm{Bq} / \mathrm{g}$ to determine the exposure dose to onsite and offsite residents at a landfill disposal facility. The $95 \%$ confidence interval for the mean specific ACs of all radionuclides in question is summarized in Figure 1.

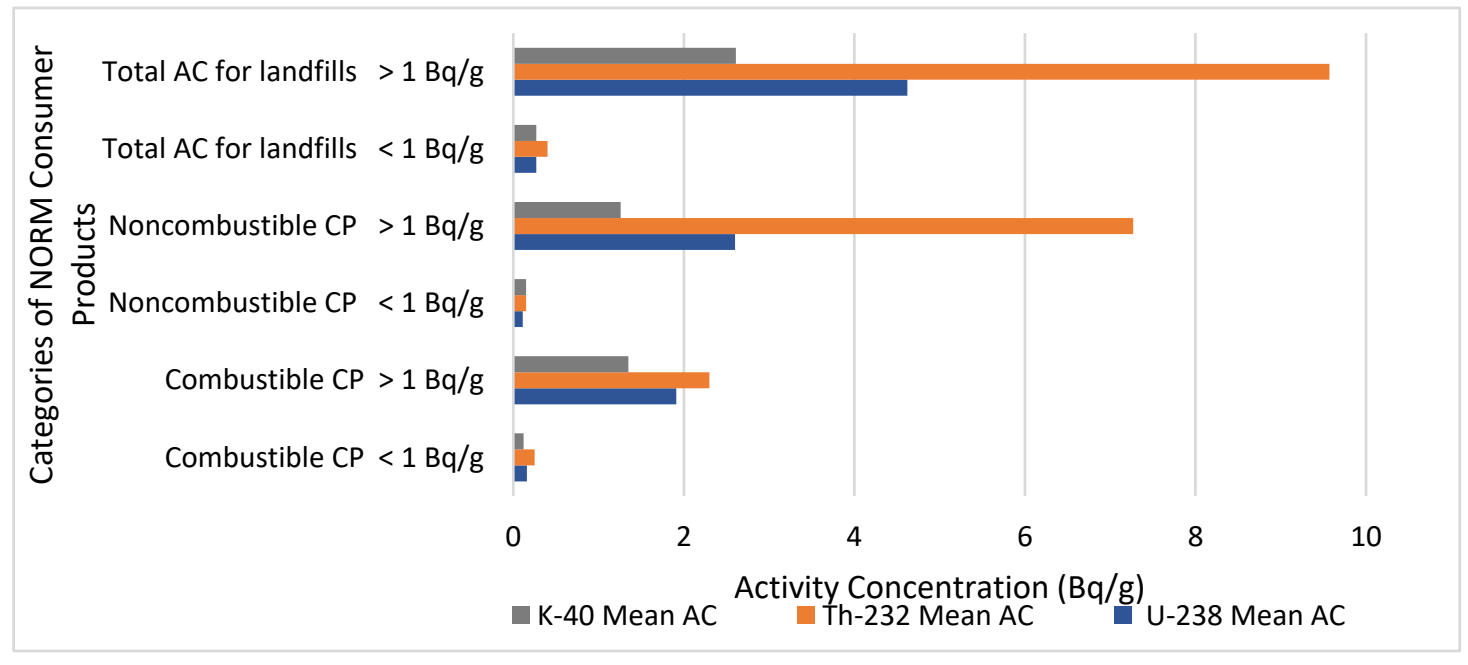

Figure 1. 95\% confidence interval for the mean activity concentration of ${ }^{238} \mathrm{U},{ }^{232} \mathrm{Th}$, and ${ }^{40} \mathrm{~K}(\mathrm{~Bq} / \mathrm{g})$. 


\subsection{Scenario Description}

The structural diagram for the assumed disposal scenarios for CPs NORMs is shown in Figure 2.

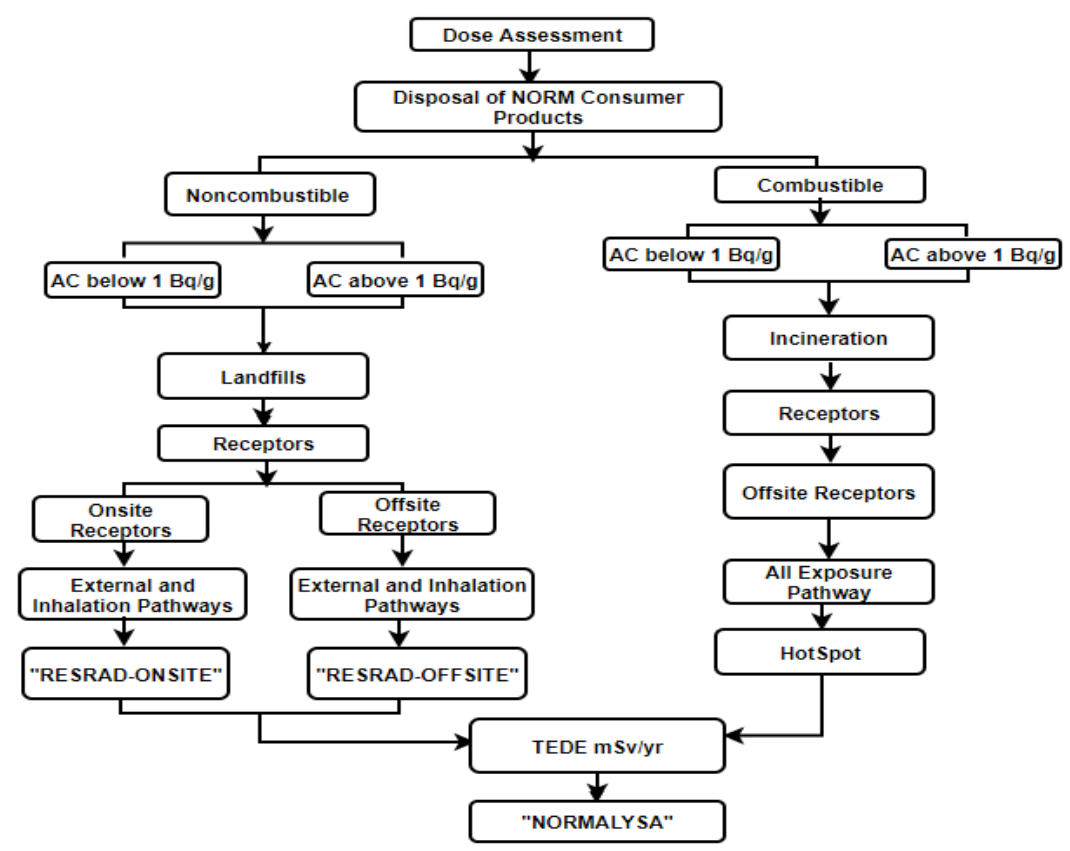

Figure 2. Summary of the scenario for the disposal of consumer products containing naturally occurring radioactive materials.

\subsubsection{Scenario of Landfill Disposal}

In this study, we assumed that noncombustible wastes from NORM-added CPs and ash residues from the incineration of NORM-added CPs are disposed of at landfill sites with other household wastes in South Korea. To calculate potential exposure dose from the landfill disposal of $\mathrm{CPs}$, the following assumptions were made. According to Korea Statistics 2018, the total number of landfill sites in South Korea is 275, and 7221.15 tons of household waste are disposed of in landfills. The total mass of household waste disposal per site would approximately be 26.26 tons/day. In South Korea, landfill sites cover an area of $659 \mathrm{~m}^{2}$.

\subsubsection{Scenario of Incineration}

Combustible wastes from NORM CPs are disposed of by incineration. The following assumptions were made in estimating the potential exposure dose from incineration of wastes from NORM-added CPs; the total number of incinerators in South Korea is 382, according to Korea Statistics 2018. Incineration is used to dispose of 13,319 tons of household waste per day. The total amount of household waste incinerated in each incinerator per day is approximately 34.86 tons/day or $34,866 \mathrm{~kg}$. The specific ACs for the incineration of various CPs containing NORMs were categorized into two ranges: below and above 1 $\mathrm{Bq} / \mathrm{g}$. For each category, the most exposed individuals are the offsite residents who live $200 \mathrm{~m}$ from the incinerator, and this was the basis used to evaluate dose using HotSpot computer code. Because HotSpot uses total activity (Bq) to estimate the offsite dose, the total AC based on the total mass of wastes burned by one incinerator was used as an input to the HotSpot code. The new input data for the HotSpot code is summarized in Table 1. 
Table 1. 95\% confidence interval for the total activity concentration (Bq).

\begin{tabular}{|c|c|c|c|c|c|c|}
\hline \multirow[b]{2}{*}{ Categories of $\mathrm{CP}$} & \multicolumn{3}{|c|}{ Specific Activity Concentration (Bq/kg) } & \multicolumn{3}{|c|}{ Total Activity (Bq) } \\
\hline & ${ }^{238} \mathrm{U}$ & ${ }^{232} \mathrm{Th}$ & ${ }^{40} \mathrm{~K}$ & ${ }^{238} \mathrm{U}$ & ${ }^{232} \mathrm{Th}$ & ${ }^{40} \mathrm{~K}$ \\
\hline Combustible (below 1000 Bq/kg) & 164 & 226 & 125 & $5.72 \times 10^{6}$ & $7.86 \times 10^{6}$ & $4.36 \times 10^{6}$ \\
\hline Combustible (above 1000 Bq/kg) & 1917 & 2320 & 1358 & $6.68 \times 10^{7}$ & $8.088 \times 10^{7}$ & $4.73 \times 10^{7}$ \\
\hline Noncombustible (below $1000 \mathrm{~Bq} / \mathrm{kg}$ ) & 114 & 153 & 150 & $3.97 \times 10^{6}$ & $5.33 \times 10^{6}$ & $5.23 \times 10^{6}$ \\
\hline Noncombustible (above 1000 Bq/kg) & 2607 & 7250 & 1310 & $9.09 \times 10^{7}$ & $2.53 \times 10^{8}$ & $4.41 \times 10^{7}$ \\
\hline Total AC for landfills (below $1000 \mathrm{~Bq} / \mathrm{kg}$ ) & 278 & 379 & 275 & $9.69 \times 10^{6}$ & $1.32 \times 10^{7}$ & $9.59 \times 10^{6}$ \\
\hline Total AC for landfills (above $1000 \mathrm{~Bq} / \mathrm{kg}$ ) & 4638 & 9570 & 2668 & $1.62 \times 10^{8}$ & $3.33 \times 10^{8}$ & $9.15 \times 10^{7}$ \\
\hline
\end{tabular}

\subsection{Methodology of RESRAD-ONSITE}

Argonne National Laboratory developed the RESRAD family of codes in the 1980s to analyze potential human and biota radiation exposures from the environmental contamination of RESRAD materials. The codes use pathway analysis to estimate radiation exposure and associated risks and develop cleanup criteria for radionuclide concentrations in the contaminated source medium. RESRAD uses a pathway analysis method to track radionuclide transport in the environment (soil, water, and air) and model how these radionuclides reach the receptor through direct exposure, ingestion, and inhalation. The code uses various dose coefficients, such as age and gender-specific DCs and methodology-based DCs from the International Commission on Radiological Protection (ICRP) publications 26, 30, and 60 [21-23]. The RESRAD-ONSITE computer code estimates the radiological dose and excess cancer risk to an individual who is exposed while living or working in a radionuclide-contaminated area. The RESRAD-ONSITE code has continuously improved in response to feedback from users and sponsors. The RESRAD team has participated in many national and international model intercomparison studies in which both hypothetical and actual contaminated site-based scenarios were analyzed using RESRAD-ONSITE [24] We assumed a resident scenario with a person settling on a former landfill site to simulate radiological dose using RESRAD-ONSITE. We assumed an urban resident scenario where the resident does not consume any food or water from the contaminated site because most South Koreans live in suburban areas. The pathways considered were external irradiation and inhalation. The code uses a Gaussian plume model, where the radionuclide concentration and plume are constant and do not change with time.

\subsection{Methodology of RESRAD-OFFSITE}

RESRAD-OFFSITE evaluates the radiological dose and excess cancer risk to an individual who is exposed while living or working in or near a radionuclide-contaminated area [25]. It evolved from RESRAD-ONSITE during the BIOMOVS II model comparison first by adding an offsite soil accumulation submodel (BIOMOVS II 1995) and then including an adjective-dispersive groundwater transport submodel (BIOMOVS II 1996). In this study, the ability to accept a time series for release from contaminated soil was also added. During participation in the multimedia model comparison study, the adjective-dispersive groundwater transport submodel was improved to better predict the transport of progeny produced in transit. An atmospheric transport submodel and a surface water body accumulation submodel were added. The computational algorithm of the RESRAD-OFFSITE code differed from that of RESRAD-ONSITE. RESRAD-ONSITE numerically evaluates the analytical expressions for concentration, dose, and risk at any desired time since the site survey, whereas RESRAD-OFFSITE numerically computes the concentration, dose, and risk progressively over time. To simulate radiological dose using RESRAD-OFFSITE, we assumed an offsite resident scenario, where a person lives within the vicinity of a landfill. Another assumption was that the person would not consume any food or water from the contaminated site; the exposure pathways considered were inhalation and external irradiation. The code uses a Gaussian plume model, where the radionuclide concentration and plume remain constant over time. 


\subsection{Methodology of HotSpot}

The HotSpot Health Physics Codes were developed to provide emergency responders and planners with a fast, field-portable set of software tools for evaluating radioactive material incidents. The software is also used for safety analyses of nuclear material handling facilities [26]. In unobstructed terrain and simple meteorological conditions, the HotSpot atmospheric dispersion models are designed for near-surface releases, short range (less than $10 \mathrm{~km}$ ) dispersion, and short-term (less than $24 \mathrm{~h}$ ) release durations. These models provide fast and conservative means of estimating the radiation effects associated with the radioactive material released into the atmosphere. The HotSpot radionuclide Library includes Federal Guidance Reports 11, 12, and 13 (FGR-11, FGR-12, and FGR-13) dose conversion factors (DCFs) for inhalation, submersion, and ground shine. FGR-12 DCF values are used for submersion and ground shine. In addition to inhalation, 50-year Committed Effective Dose Equivalent DCFs, acute (1, 4, and 30 days) DCFs are available for estimating deterministic effects. This acute mode is used to estimate the immediate radiological impact of high-acute radiation doses (applicable target organs are the lung, small intestine wall, and red bone marrow). The Department of Energy funds the HotSpot Health Physics Codes' ongoing maintenance and development. Since 1988, the HotSpot program has been distributed worldwide. HotSpot codes are conservative (estimated radiation dose data are usually greater) estimates of the radiation effects associated with the radioactive material atmospheric release. HotSpot codes provide a first-order approximation of radiation effects due to the atmospheric release of radionuclides. The code evaluates any incidents involving radioactive substances so that the first responder can take appropriate measures to respond to the incidents.

\subsection{Governing Equation of RESRAD and HotSpot}

RESRAD-ONSITE, RESRAD-OFFSITE, and HotSpot computer codes all use a Gaussian plume model derived from a three-dimensional (3-D) equation for atmospheric diffusion to evaluate radionuclide concentration. The 3-D diffusion equation for atmospheric diffusion is given as follows:

$$
\frac{\partial X}{\partial t}=\frac{\partial}{\partial x}\left[P_{x}\left(\frac{\partial X}{\partial x}\right)\right]+\frac{\partial}{\partial y}\left[P_{y}\left(\frac{\partial X}{\partial y}\right)\right]+\frac{\partial}{\partial z}\left[P_{z}\left(\frac{\partial X}{\partial z}\right)\right]
$$

where

$x, y$, and $z=$ downwind, cross-wind, and vertical directions, and

$P_{x}, P_{y}, P_{z}=$ diffusivity in $x$-, $y$ - and $z$-directions, respectively.

The Gaussian plume model is given by the following equation:

$$
C(x, y, z)=\frac{Q}{2 \pi \sigma_{y}(x) \sigma_{z} u} \exp \left\{-\frac{1}{2}\left[\frac{y}{\sigma_{y}}\right]^{2}\right\} \times\left(\exp \left\{-\frac{1}{2}\left[\frac{z-H}{\sigma_{z}}\right]^{2}\right\}+\exp \left\{-\frac{1}{2}\left[\frac{z \mp H}{\sigma_{z}}\right]^{2}\right\}\right) \times \exp \left[\frac{\lambda x}{u}\right] \operatorname{DF}(x)
$$

However, if the $\sigma_{z}$ exceeds the inversion height $(\mathrm{L})$, the following relation is used:

$$
T(x, y, z)=\frac{R}{2 \pi \sigma_{y} L u} \exp \left\{-\frac{1}{2}\left[\frac{y}{\sigma_{y}}\right]^{2}\right\} \exp \left[-\frac{\lambda x}{u}\right] \operatorname{PDF}(x)
$$

where

$T=$ time-integrated atmospheric concentration $(\mathrm{Ci}-\mathrm{s}) /\left(\mathrm{m}^{3}\right)$;

$R=$ source term $(\mathrm{Ci})$;

$H=$ effective release height $(\mathrm{m})$;

$\lambda=$ radioactive decay constant (s-1);

$x=$ downwind distance $(\mathrm{m})$;

$y=$ crosswind distance $(\mathrm{m})$; 
$z=$ vertical axis distance $(\mathrm{m})$;

$\sigma_{y}=$ standard deviation of integrated concentration distribution in the crosswind direction (m);

$\sigma_{z}=$ standard deviation of the integrated concentration distribution in the vertical direction (m);

$u=$ average wind speed at the effective release height;

$L=$ inversion layer height $(\mathrm{m})$;

$\operatorname{PDF}(x)=$ plume depletion factor.

\subsection{Methodology of NORMALYSA}

NORMALYSA is a software designed to simulate radionuclide transport from a source, such as a radioactively contaminated land, to relevant receptors in the environment (e.g., residential areas, agricultural areas, and water bodies) and calculate radiation exposure doses to humans [27]. NORMALYSA was developed in Sweden by Facilia AB with support from the IAEA. It has been tested and benchmarked against other similar software tools as part of the IAEA-Modeling and Data for Radiological Impact Assessments project Work Group 3 (NORM and Radioactively Contaminated LegacY Sites) activities. It is summarized into four modeling steps of estimating the radiological dose from different pathways. The NORMALYSA modeling steps are shown in Table 2.

Table 2. Modeling Steps in NORM and LegacY Site Assessment code.

\begin{tabular}{cc}
\hline Modelling Steps & Description \\
\hline Context model options & To define model structure \\
Time series parameters & To specify parameters models \\
Simulation & To carry out calculation \\
Charts, tables, and reports & To analyze and report results \\
\hline
\end{tabular}

Figure 3 summarizes the four main libraries of NORMALYSA. The "Sources" library includes modules for calculating radionuclide releases (source term) from uranium mill and other radioactively contaminated lands. The "Transports" library includes modules for calculating radionuclide transport from the contaminated source to different receptors through atmospheric, groundwater, or surface runoff. The "Receptors" library includes modules for calculating radionuclide transfer and redistribution processes in different receptor environments. The doses are calculated for various relevant exposure pathways (e.g., external irradiation, inhalation, and ingestion) and can be summed into a total annual effective dose in Sv/year. NORMALYSA uses the previously recommended and documented environmental transport and exposure assessment models that are relatively simple. In particular, NORMALYSA uses models used in the Swedish Nuclear Fuel and Waste Management Company's safety assessment of radioactive waste disposal facilities and generic models recommended by the IAEA (e.g., from the IAEA SRS-19 report).
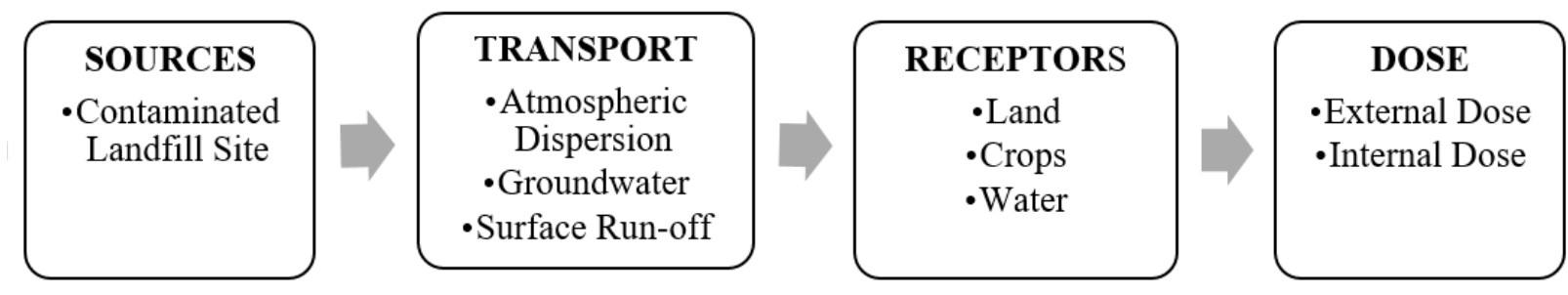

Figure 3. Main libraries in NORM and LegacY Site Assessment.

In this study, we used the contaminated land module, which simulates contaminated land where individuals can be exposed through external irradiation, inhalation, and inadvertent ingestion of contaminated soil, although the ingestion pathway was not considered. The mathematical models used are as follows: 
Mass balance equation for soil media is given by the following equation:

$$
\begin{aligned}
& d \text { Soil_RZ } / d t=D e p+I r r+S_{0 i l}(D Z) \times \text { Erosion_ }(D Z)+S_{0 i l}(D Z) \times b i o T_{-}(D Z)
\end{aligned}
$$

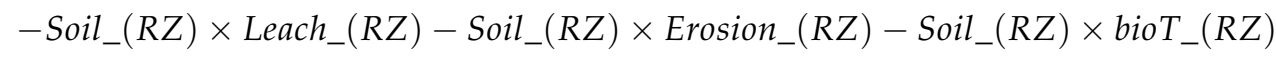

$$
\begin{aligned}
& -\lambda \times S_{0} i_{-}(R Z)+\sum_{-}(p \in P) B r_{-}(p) \times \lambda \times S_{0 i l} R Z Z^{p} p
\end{aligned}
$$

where

$D e p=$ total deposition of radionuclides from the atmosphere to the receptor area $(\mathrm{Bq} /$ year); $I r r=$ transfer of radionuclides to the receptor area with irrigation water $(\mathrm{Bq} /$ year $)$;

Soil_ $(D Z)=$ radionuclide inventory in the deep zone of soil $(\mathrm{Bq})$;

Erosion_ $(D Z)=$ transfer coefficient of radionuclide from deep soil zone to rooting zone to compensate for erosion losses from the rooting zone (1/year);

bioT_ $(D Z)=$ transfer coefficient of radionuclide from the deep soil to the rooting zone due to bioturbation (1/year);

Leach_ $(R Z)=$ transfer coefficient of radionuclides from the root zone to the deep zone by leaching (1/year);

Erosion_ $(R Z)=$ transfer coefficient of radionuclides from the rooting zone due to the erosion process (1/year);

$b i o T_{-}(R Z)=$ transfer coefficient of radionuclide from the rooting soil to the deep zone due to bioturbation (1/year).

The two last right-hand side terms in the equation describe the radioactive decay and ingrowth of radionuclides from the parent nuclides in the root zone. Radionuclide concentration in outdoor air is calculated using the following equation:

$$
C_{-}(\text {air }, \text { resusp })=C_{-} \text {soil } \times C_{-} \text {dust }
$$

where

$C_{-}($air, resusp $)=$concentration in outdoor air from resuspension $\left(\mathrm{Bq} / \mathrm{m}^{3}\right)$;

C_soil $=$ radionuclide concentration in the receptor topsoil $\left(\mathrm{Bq} / \mathrm{kg} . \mathrm{DW} / \mathrm{m}^{3}\right)$;

C_dust $=$ concentration of dust in atmospheric air $\left(\mathrm{Kg} . \mathrm{DE} / \mathrm{m}^{3}\right)$.

The dose from occupancy outdoors was also used to calculate the total annual effective dose to receptors during outdoor activities. The exposure pathways considered were external exposure and inhalation pathway. Finally, the total dose module was used to calculate the sum of all relevant radionuclides and exposure pathways; the total dose is given by the following equation:

$$
\text { Dose_total }=\text { Dose_(ext, total })+ \text { Dose_(inh, total })
$$

where

Dose_(ext,total $)=$ Total dose from external exposure;

Dose_(inh, total $)=$ total dose from inhalation exposure.

The NORMALYSA modules used in the current study are summarized in Figure 4.

Table 3 summarizes the advantages and disadvantages of models used by various computer codes in this study. 
Table 3. Comparison of models used in this study.

\begin{tabular}{|c|c|c|c|}
\hline Codes & Models & Advantage & Disadvantage \\
\hline RESRAD-ONSITE & Gaussian plume model & $\begin{array}{l}\text { Evaluates radiological dose and risk } \\
\text { to onsite receptors }\end{array}$ & $\begin{array}{l}\text { Low wind speed condition, no memories of } \\
\text { previous emission }\end{array}$ \\
\hline RESRAD-OFFSITE & Gaussian plume model & $\begin{array}{l}\text { Evaluates radiological dose and risk } \\
\text { to offsite receptors }\end{array}$ & Breaks down during low wind speed condition \\
\hline HotSpot & $\begin{array}{c}\text { Atmospheric dispersion } \\
\text { model }\end{array}$ & $\begin{array}{l}\text { Evaluates incident involving } \\
\text { radioactive materials }\end{array}$ & Estimate the short range (less than $10 \mathrm{~km}$ ) \\
\hline NORMALYZA & Gaussian plume model & $\begin{array}{l}\text { Simulate radionuclide transport } \\
\text { from contaminated land to relevant } \\
\text { receptors }\end{array}$ & $\begin{array}{l}\text { Low wind speed condition, no memories of } \\
\text { previous emission }\end{array}$ \\
\hline
\end{tabular}

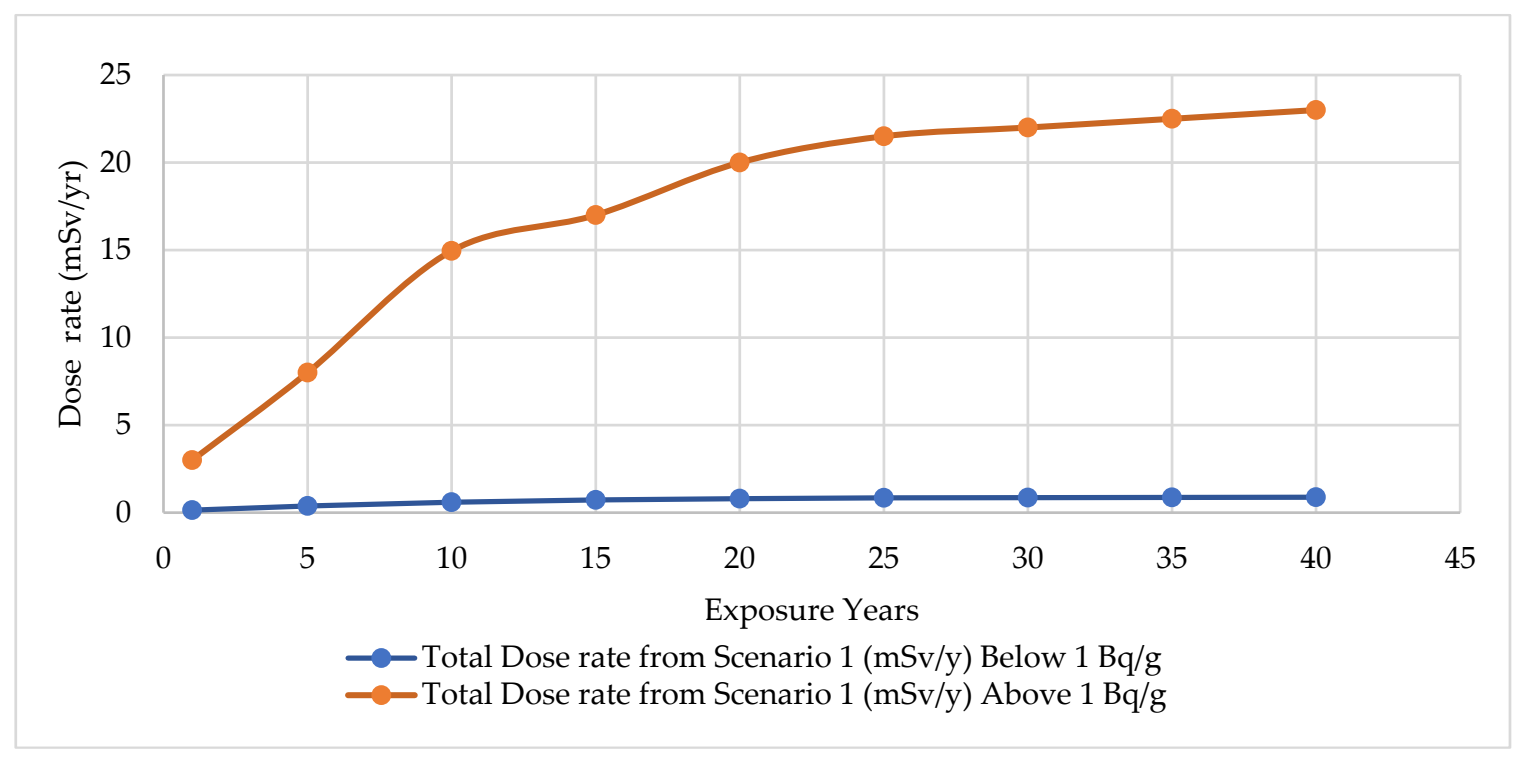

Figure 4. Results from RESRAD ONSITE scenario.

\section{Results}

In this scenario, we assumed that no meat and milk obtained from the site would be consumed and that the water used for drinking would come from a non-contaminated source. External irradiation and inhalation pathways were considered. The external pathway was used in this study because one of the NORM used was potassium 40, which emits both beta particles and gamma rays that humans are exposed to externally. Uranium and thorium are alpha emitters and lack the energy to penetrate even the outer layer of the skin, and therefore external exposure is not the main concern; however, they can be fatal when inside the body. The input values used in RESRAD codes are shown in Table 4.

Figure 4 shows the results for RESRAD-ONSITE for a resident scenario with AC below and above $1 \mathrm{~Bq} / \mathrm{g}$. In this scenario, we calculated the total dose ( $\mathrm{mSv} / \mathrm{y})$ obtained from RESRAD-ONSITE with AC ranges below and above $1 \mathrm{~Bq} / \mathrm{g}$ for an onsite resident who settles on a former landfill site contaminated with CPs containing NORMs. The pathways considered were inhalation and external exposure pathways using a modeling period of 40 years. The radiological dose rate for ACs above $1 \mathrm{~Bq} / \mathrm{g}$, as indicated by the orange values, was high, with a maximum value of $2.30 \mathrm{E}+01 \mathrm{mSv} / \mathrm{y}$. This was due to the high AC that is caused by the inhalation of radon and thoron decay products with little contribution to the external pathway from the decay of ${ }^{40} \mathrm{~K}$. The radiological dose for AC below $1 \mathrm{~Bq} / \mathrm{g}$, indicated by the blue line, shows that the values were all below the ICRP-recommended public dose limit of $1 \mathrm{mSv} / \mathrm{y}$, with a maximum value of $8.80 \mathrm{E}-01 \mathrm{mSv} / \mathrm{y}$ because of the low AC considered in the simulation.

Figure 5 shows the total dose rate $(\mathrm{mSv} / \mathrm{y})$ obtained from the RESRAD-OFFSITE scenario with $\mathrm{AC}$ ranges below and above $1 \mathrm{~Bq} / \mathrm{g}$. In this scenario, the offsite resident 
was assumed to live within the vicinity of a landfill site but does not eat or drink water from the contaminated site. The only exposure pathway considered in this scenario was the inhalation of radon and thoron decay products of NORMs over a 40-year modeling period. The total dose for both categories of $\mathrm{AC}$ is below the ICRP-recommended public dose limit of $1 \mathrm{mSv} / \mathrm{y}$, with the highest dose of $5.28 \mathrm{e}-03 \mathrm{mSv} / \mathrm{y}$ for AC below $1 \mathrm{~Bq} / \mathrm{g}$ and $0.132 \mathrm{mSv} / \mathrm{y}$ for AC above $1 \mathrm{~Bq} / \mathrm{g}$, respectively. These results show that it is safe for people to reside within a vicinity of a landfill site as offsite residents.

Table 4. Input values used in RESidual RADioactive codes.

\begin{tabular}{|c|c|c|}
\hline Input Parameter & Value & Source \\
\hline Concentration below $1 \mathrm{~Bq} / \mathrm{g}$ & & NSSC \\
\hline${ }^{238} \mathrm{U}$ & $0.20 \mathrm{~Bq} / \mathrm{g}$ & \\
\hline${ }^{232} \mathrm{Th}$ & $0.40 \mathrm{~Bq} / \mathrm{g}$ & \\
\hline${ }^{40} \mathrm{~K}$ & $0.27 \mathrm{~Bq} / \mathrm{g}$ & \\
\hline Concentration above $1 \mathrm{~Bq} / \mathrm{g}$ & & NSSC \\
\hline${ }^{238} \mathrm{U}$ & $4.62 \mathrm{~Bq} / \mathrm{g}$ & \\
\hline${ }^{232} \mathrm{Th}$ & $9.57 \mathrm{~Bq} / \mathrm{g}$ & \\
\hline${ }^{40} \mathrm{~K}$ & $2.61 \mathrm{~Bq} / \mathrm{g}$ & \\
\hline Exposure duration & 30 years & RESRAD default \\
\hline Area of the contamination zone & $659 \mathrm{~m}^{2}$ & Korea statistics, 2018 \\
\hline Density of cover material & $1.5 \mathrm{~g} / \mathrm{cm} 3$ & RESRAD default \\
\hline Cover depth & $0 \mathrm{~m}$ & RESRAD default \\
\hline Thickness of the contaminated zone & $2 \mathrm{~m}$ & RESRAD default \\
\hline Density of the contaminated zone & $1.5 \mathrm{~g} / \mathrm{cm}^{3}$ & RESRAD default \\
\hline Inhalation rate for onsite resident & $8400 \mathrm{~m}^{3} /$ year & RESRAD default \\
\hline Inhalation rate for industrial workers & $11,400 \mathrm{~m}^{3} /$ year & RESRAD default \\
\hline Cover radon diffusion coefficient & $0.000002 \mathrm{~m}^{2} / \mathrm{s}$ & RESRAD default \\
\hline Contaminated radon diffusion coefficient & $0.000002 \mathrm{~m}^{2} / \mathrm{s}$ & RESRAD default \\
\hline Distribution coefficient of the contaminated zone & $100 \mathrm{~cm}^{3} / \mathrm{g}$ & RESRAD default \\
\hline \multicolumn{3}{|l|}{ Transport factors } \\
\hline $238 \mathrm{U}$ & $5.5 \mathrm{~cm}^{3} / \mathrm{g}$ & \\
\hline${ }^{232} \mathrm{Th}$ & $60,000 \mathrm{~cm}^{3} / \mathrm{g}$ & RESRAD default \\
\hline${ }^{40} \mathrm{~K}$ & $50 \mathrm{~cm}^{3} / \mathrm{g}$ & \\
\hline Release height & $2 \mathrm{~m}$ & Assumed value \\
\hline Outdoor fraction & 0.25 & RESRAD default \\
\hline Indoor fraction & 0.5 & RESRAD default \\
\hline
\end{tabular}

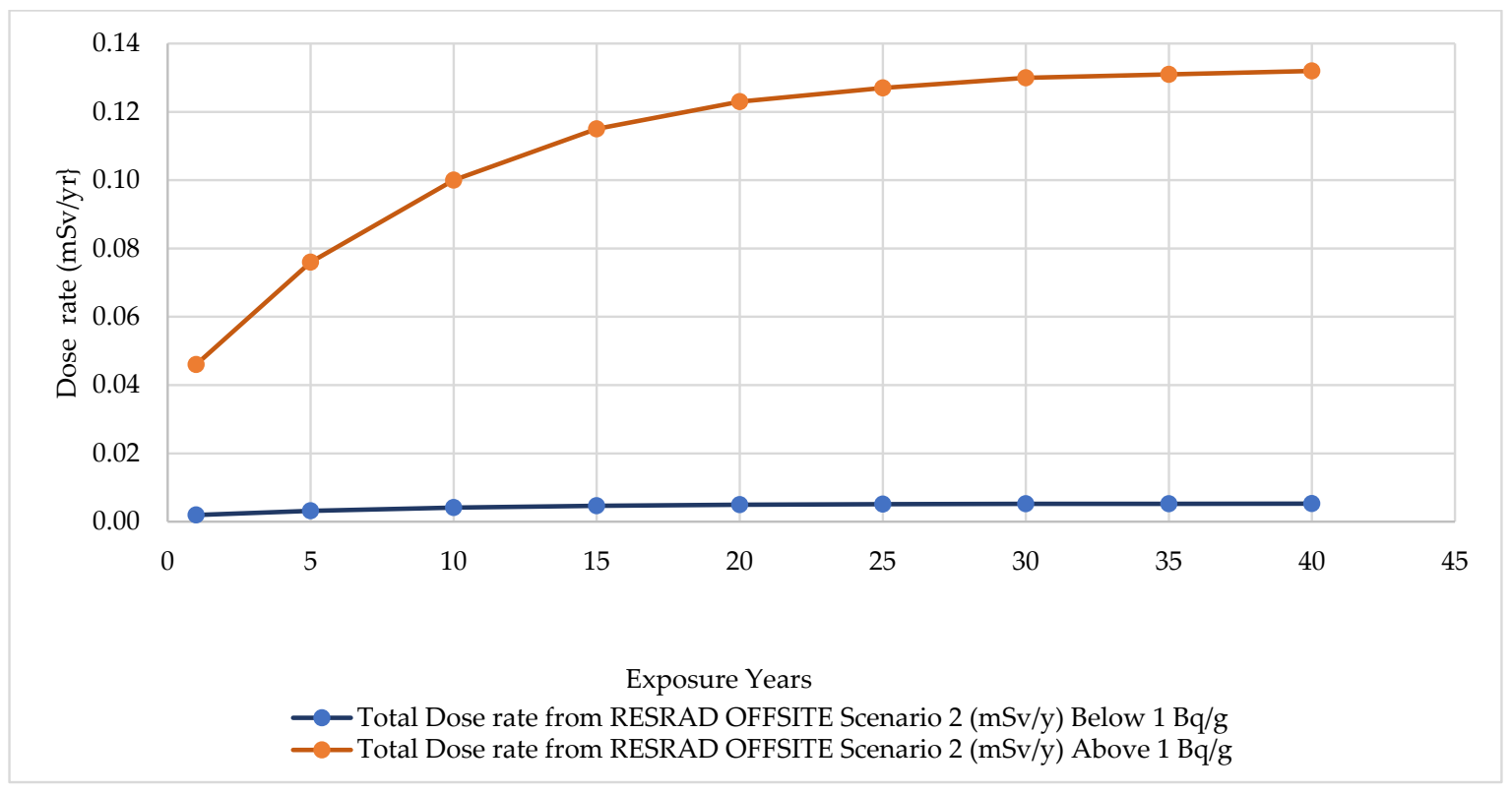

Figure 5. Dose from the RESRAD-OFFSITE scenario. 
Table 5 summarizes all input parameters considered in calculating radiological dose from the incineration of CPs containing NORMs. The HotSpot module considered in this study was the general fire module.

Table 5. Input values used in HOTSPOT.

\begin{tabular}{cc}
\hline Parameters & Values \\
\hline Source material below and above $1000 \mathrm{~Bq} / \mathrm{kg}$ & $\mathrm{AC} \mathrm{of}{ }^{238} \mathrm{U},{ }^{232} \mathrm{Th}$, and ${ }^{40} \mathrm{~K}$ \\
Receptors height & $5 \mathrm{~m}$ \\
Sample time & $40 \mathrm{~min}$ \\
Effective release height & $7 \mathrm{ft}$ \\
Atmospheric stability & Sun high in the sky \\
Wind speed & $2.24 \mathrm{mph}$ \\
Wind direction & 270 \\
Wind speed & $10 \mathrm{~m} / \mathrm{s}$ \\
Stability class & $\mathrm{A}$ \\
Breathing rate & $3.33 \times 10^{-4} \mathrm{~m}^{3} / \mathrm{s}$ \\
\hline
\end{tabular}

As shown in Figure 6, the highest dose for stability class A was $0.47 \mathrm{mSv} / \mathrm{y}$ at a distance of $0.03 \mathrm{~km}$ from the release point for AC below $1000 \mathrm{~Bq} / \mathrm{kg}$. The dose dispersed within a distance of $10 \mathrm{~km}$ from the release point depends on the stability class, receptor height, long sampling time used, and the effect of meteorological conditions considered in the study. Thin lines were used for clarity. Therefore, people living within the vicinity of 10 $\mathrm{km}$ from the release point tend to be more exposed than those living outside the boundary of the release point.

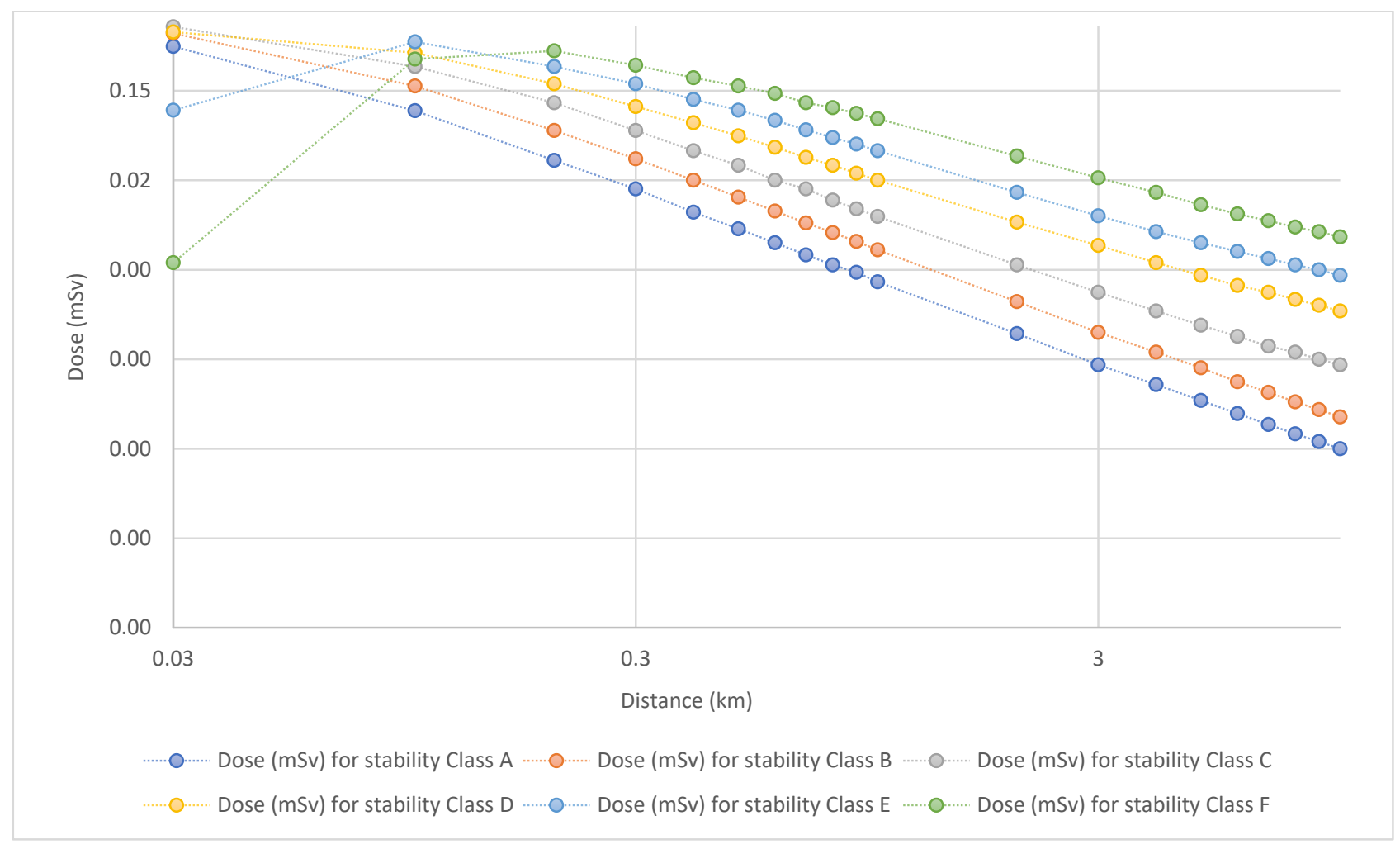

Figure 6. Dose from the HotSpot code for activity concentration below $1000 \mathrm{~Bq} / \mathrm{kg}$.

As shown in Figure 7, the highest dose for stability class A at a distance of $0.03 \mathrm{~km}$ from the release point for ACs above $1000 \mathrm{~Bq} / \mathrm{kg}$ was $4.3 \mathrm{mSv} / \mathrm{y}$, which was above the ICRP-recommended public dose limit of $1 \mathrm{mSv} / \mathrm{y}$. Just as shown in Figure 6, thin lines 
were used for clarity. The dose shown in Figure 8 was much higher than the dose shown in Figure 6 because of the high AC above $1000 \mathrm{~Bq} / \mathrm{kg}$. People are not advised to live within $10 \mathrm{~km}$ of the incinerator because it makes them prone to higher exposure doses.

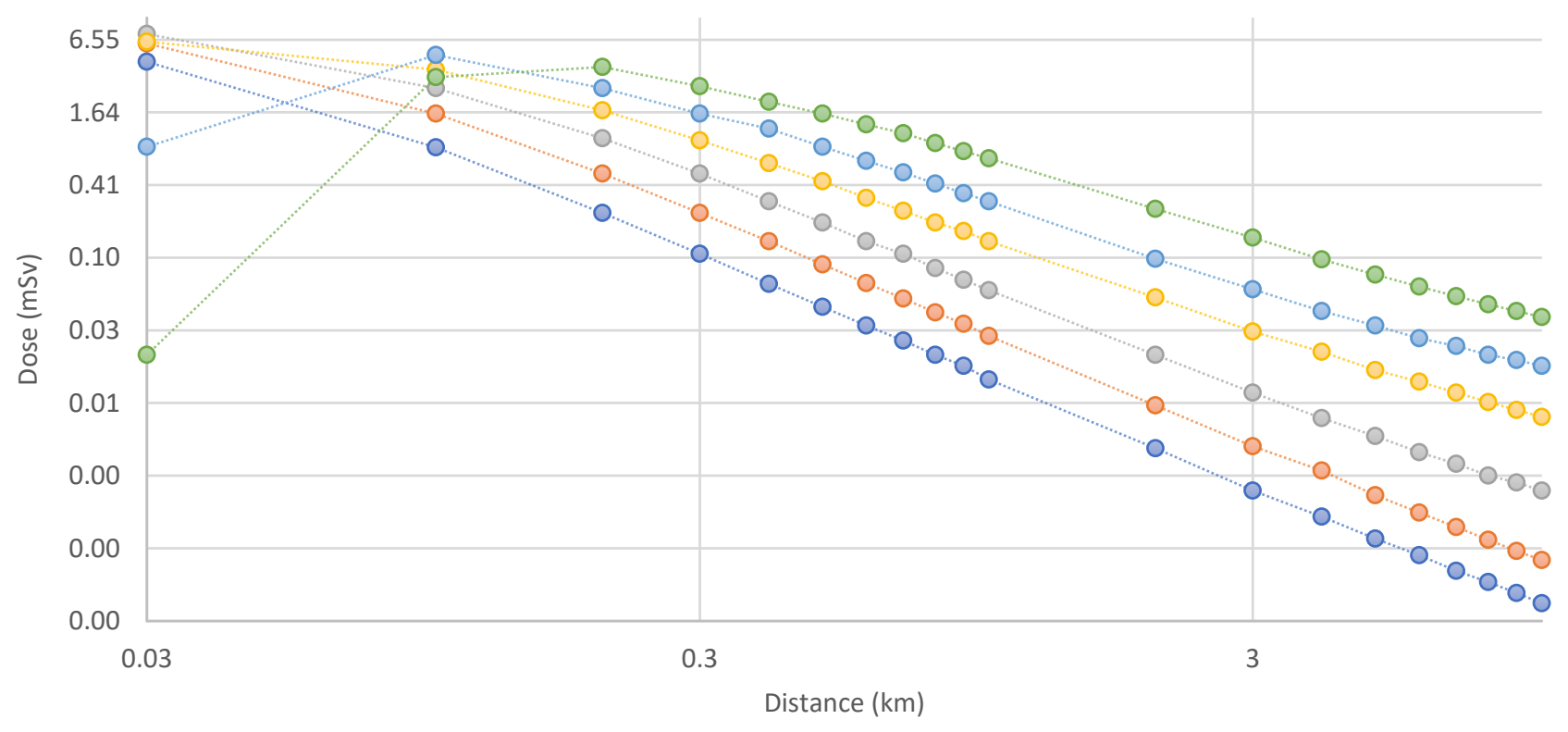

.......... Dose (mSv) for stability class A …....... Dose (mSv) for stability class B …....... Dose (mSv) for stability class C

......... Dose (mSv) for stability class D ........... Dose (mSv) for stability class E …........ Dose (mSv) for stability class $F$

Figure 7. Dose from the HotSpot code for activity concentration above $1000 \mathrm{~Bq} / \mathrm{kg}$.

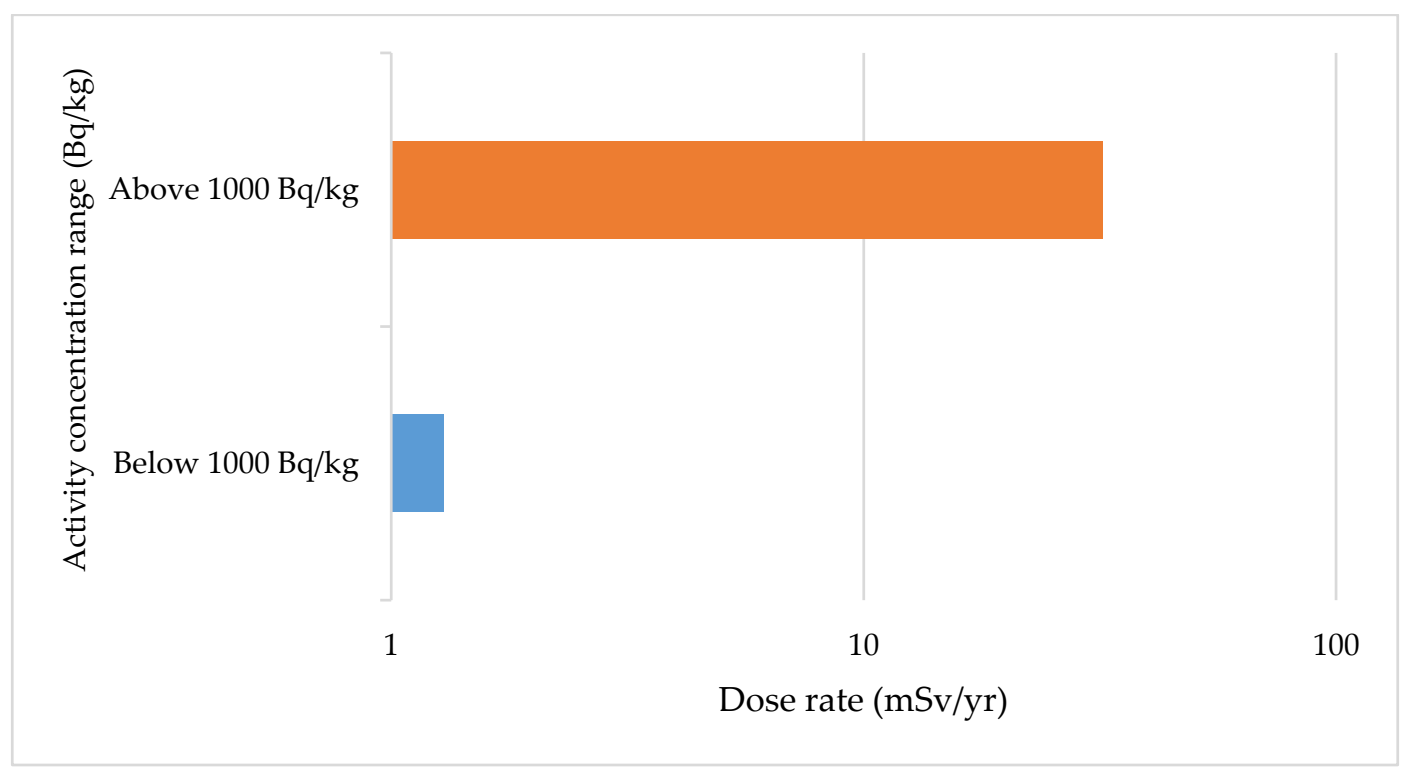

Figure 8. Dose from the NORM and LegacY Site Assessment code.

A similar scenario used in RESRAD-ONSITE code was used in NORMALYSA to validate the dose obtained from RESRAD-ONSITE. External exposure and inhalation were the pathways considered. Radionuclide concentrations in the contaminated landfill and air of the contaminated site were used as input data for dose calculations. Table 6 summarizes all input parameters used in calculating the dose using NORMALYSA computer code. 
Table 6. Summary of NORM and LegacY Site Assessment input parameters.

\begin{tabular}{|c|c|c|}
\hline Input Parameter & Value & Reference \\
\hline Activity concentration & Same as RESRAD & NSSC \\
\hline \multirow{2}{*}{\multicolumn{3}{|c|}{ Concentration of radionuclides in outdoors air }} \\
\hline & $6.0 \times 10^{-8} \mathrm{~Bq} / \mathrm{m}^{3}$ & \multirow{3}{*}{ [28] } \\
\hline${ }^{232} \mathrm{Th}$ & $2.0 \times 10^{-7} \mathrm{~Bq} / \mathrm{m}^{3}$ & \\
\hline${ }^{40} \mathrm{~K}$ & $2.9 \times 10^{-10} \mathrm{~Bq} / \mathrm{m}^{3}$ & \\
\hline $\begin{array}{c}\text { Fraction of the year a person stays within the } \\
\text { contaminated site }\end{array}$ & 0.25 & RESRAD default \\
\hline Soil bulk density & $1.5 \mathrm{~g} / \mathrm{cm}^{3}$ & RESRAD default \\
\hline Ambient external dose rate outdoors & $1.2 \times 10^{-7} \mathrm{~Sv} / \mathrm{h}$ & NORMALYSA default \\
\hline Conversion factor from ambient to effective dose & 0.6 & NORMALYSA default \\
\hline \multicolumn{3}{|l|}{ Dose coefficient for effective dose by inhalation } \\
\hline${ }^{238} \mathrm{U}$ & $8.0 \times 10^{-8}$ & \\
\hline${ }^{232} \mathrm{Th}$ & $1.1 \times 10^{-4}$ & \\
\hline${ }^{40} \mathrm{~K}$ & $2.9 \times 10^{-9}$ & NORMALYSA default \\
\hline Time of calculation & 1000 years & Same as RESRAD \\
\hline Area of contaminated site & $659 \mathrm{~m}^{2}$ & Korea Statistics 2018 \\
\hline
\end{tabular}

The main input data to the NORMALYSA code for the exposure dose evaluation was $\mathrm{AC}$, which was categorized into two groups, below and above $1 \mathrm{~Bq} / \mathrm{g}$, as used in RESRAD codes. The results for both categories of $\mathrm{AC}$ are summarized in Figure 8. The total dose obtained using NORMALYSA code with AC below $1000 \mathrm{~Bq} / \mathrm{kg}$ over the modeling period of 40 years was $1.29 \mathrm{mSv} / \mathrm{y}$, which is above the ICRP-recommended public dose limit of $1 \mathrm{mSv} / \mathrm{y}$. However, the total dose from AC above $1000 \mathrm{~Bq} / \mathrm{kg}$ was $32 \mathrm{mSv} / \mathrm{y}$, which is significantly above $1 \mathrm{mSv} / \mathrm{y}$. This high dose was due to the high AC that is mainly contributed by ${ }^{232} \mathrm{Th}$. In comparison, the results from RESRAD-ONSITE and NORMALYSA codes were significantly high, and people should not settle on NORM-contaminated landfill sites without regulatory control.

Figure 9 compares the results for RESRAD-ONSITE, RESRAD-OFFSITE, HotSpot, and NORMALYSA codes. For RESRAD-ONSITE, doses for ACs above $1 \mathrm{~Bq} / \mathrm{g}$ were high, with a maximum value of $2.30 \mathrm{E}+01 \mathrm{mSv} / \mathrm{y}$, because of high ACs that are mainly contributed by the inhalation of radon and thoron decay products, whereas doses for ACs below $1 \mathrm{~Bq} / \mathrm{g}$ were all below the ICRP-recommended public dose limit of $1 \mathrm{mSv} / \mathrm{y}$, with a maximum value of $8.80 \mathrm{E}-01 \mathrm{mSv} / \mathrm{y}$, because of a significant low $\mathrm{AC}$ considered in the simulation. The total dose obtained from RESRAD-OFFSITE for AC ranges below and above $1 \mathrm{~Bq} / \mathrm{g}$ for an offsite resident was below the ICRP-recommended public dose limit of $1 \mathrm{mSv} / \mathrm{y}$. Therefore, it is safe for people to reside within a vicinity of a landfill site as offsite residents. The highest dose obtained using the HotSpot code for stability class A with ACs below and above $1000 \mathrm{~Bq} / \mathrm{kg}$ at a distance of $0.03 \mathrm{~km}$ from the release point was $0.47 \mathrm{mSv} / \mathrm{y}$, which is below the ICRP-recommended dose limit of $1 \mathrm{mSv} / \mathrm{y}$, and $4.3 \mathrm{mSv} / \mathrm{y}$, which is above the ICRP-recommended public dose limit of $1 \mathrm{mSv} / \mathrm{y}$. Higher doses were due to high ACs above $1000 \mathrm{~Bq} / \mathrm{kg}$. The total dose from NORMALYSA code with AC below $1000 \mathrm{~Bq} / \mathrm{kg}$ was $1.29 \mathrm{mSv} / \mathrm{y}$, which is above the ICRP-recommended public dose limit of $1 \mathrm{mSv} / \mathrm{y}$, whereas the total dose from $\mathrm{AC}$ above $1000 \mathrm{~Bq} / \mathrm{kg}$ was $32 \mathrm{mSv} / \mathrm{y}$, which is significantly above $1 \mathrm{mSv} / \mathrm{y}$. The high dose is attributed to the high AC, which is mainly caused by the decay of ${ }^{238} \mathrm{U}$ and ${ }^{232} \mathrm{Th}$. Therefore, people should not settle on NORM-contaminated landfill sites without clearance from the competent authority. 


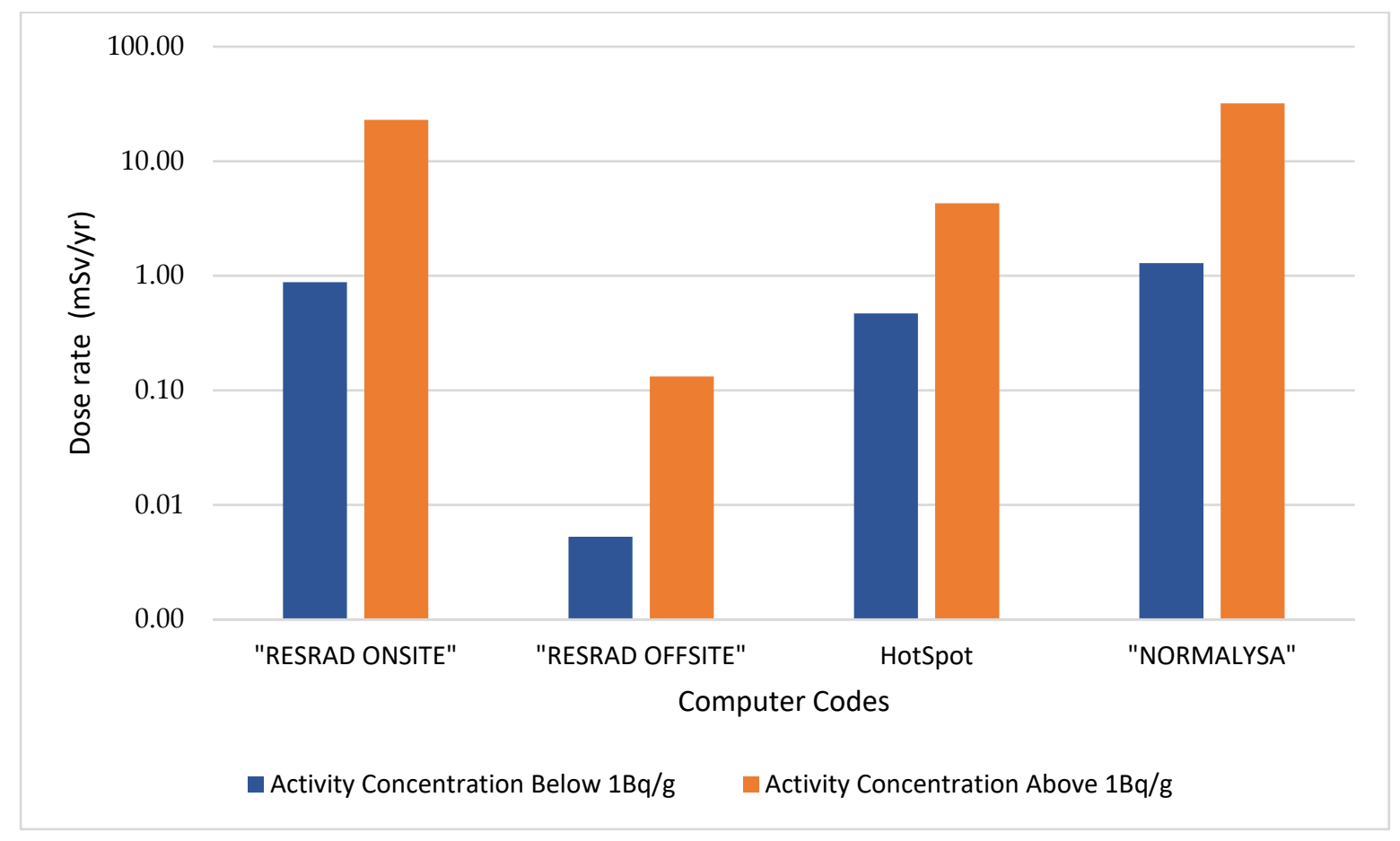

Figure 9. Comparison graph for the four computer codes.

\section{Discussion}

In this study, evaluation of radiological dose from landfill disposal of CPs containing naturally occurring radioactive materials in South Korea was conducted using various ranges of $\mathrm{AC}$ below $1 \mathrm{~Bq} / \mathrm{g}$ and above $1 \mathrm{~Bq} / \mathrm{g}$. Results for RESRAD-ONSITE for AC below $1 \mathrm{~Bq} / \mathrm{g}$ show that the doses were below the ICRP recommended public dose limit of $1 \mathrm{mSv} / \mathrm{y}$ for both pathways, which makes the site safe for onsite dwellers. For AC above $1 \mathrm{~Bq} / \mathrm{g}$, the dose was far above the recommended public dose limit of $1 \mathrm{mSv} / \mathrm{y}$ for all pathways considered, which makes the landfill sites hazardous for onsite dwellers; hence, the competent authority needs to provide further protection actions to ensure that the public is safe from unjustified radiation exposure. Results from RESRAD-OFFSITE show that dose from both categories of $\mathrm{AC}$ ranges were all below the public dose limits of $1 \mathrm{mSv} / \mathrm{y}$, which makes it safe for offsite dwellers and visitors to live within the vicinity of a landfill site. The results of HotSpot code from incineration of NORM waste considering inhalation pathway to the offsite dwellers for $\mathrm{AC}$ below $1 \mathrm{~Bq} / \mathrm{g}$ were all less than the public dose limit for all stability classes considered, while for $\mathrm{AC}$ above $1 \mathrm{~Bq} / \mathrm{g}$, the doses were all above the specified IRCP dose limit.

Thus, people living within the vicinity of $10 \mathrm{~km}$ from the incinerator are prone to unjustified exposure from incineration of CPs containing naturally occurring radioactive materials. This is due to gaseous decay of NORMs incorporated in the incinerated waste. People living outside $10 \mathrm{~km}$ from the release point are safer from unjustified exposure from the incinerator. Therefore, the competent authority needs to apply a protection action for people living at a close distance to the incinerator. Comparison of results of RESRADONSITE with the results of NORMALYZA code show that the dose for both categories of activity concentration are all above the public dose limit recommended by the ICRP. Therefore, it is not advisable for people to settle on a former landfill site without clearance from the competent authority. This is key to limit undue and unjustifiable radiation exposure to the general public. Comparison of results from all the codes used in this study show that landfill sites with activity concentration above $1 \mathrm{~Bq} / \mathrm{g}$ are not safe for dwellers until further clearance is given from the competent authority. Moreover, evacuation is recommended for people living within the vicinity of the incinerator. This is due to the 
release of gaseous decay of NORMs that contaminate the atmosphere, giving rise to high inhalation dose.

\section{Conclusions}

The ICRP dose limits are intended to serve as a margin state by avoiding deterministic consequences and regulating the possibility of stochastic effects. Doses above $1 \mathrm{mSv} / \mathrm{y}$ require the implementation of public protection measures. In this study, the radiological dose from the disposal of CPs containing NORMs was performed using appropriate dose assessment tools: RESRAD-ONSITE, RESRAD-OFFSITE, HotSpot, and NORMALYSA computer codes. Household wastes containing NORM-added CPs were categorized into combustible and noncombustible CPs. These were further classified based on the range of their AC (i.e., below and above $1 \mathrm{~Bq} / \mathrm{g}$ ). This was to ensure that all outliers were considered to obtain a more accurate value after dose calculations. All AC values for CPs containing NORMs were below $10 \mathrm{~Bq} / \mathrm{g}$, which is acceptable by the NSSC of South Korea for the landfill disposal of such waste. The competent authority needs to apply a protection action for the people living at a close distance that is within $10 \mathrm{~km}$ from the incinerator and landfill sites for the purpose of public health. In previous studies, much research has been conducted on the disposal of NORMs, such as TENORMS, VLLW, and other industrial waste; however, no research has been conducted on the landfill disposal of CPs containing NORMs. CPs containing NORMs are widely used around the world, and it is critical to assess their safety, particularly how and where they are disposed of, to ensure the safety of people and the environment.

Author Contributions: Conceptualization, M.N. and J.K.; methodology, M.N.; software, J.K.; validation, M.N. and J.K.; formal analysis, M.N.; investigation, J.K. and M.N.; resources, J.K. and M.N.; data curation, M.N.; writing-original draft preparation, M.N.; writing—review and editing, J.K.; visualization, M.N.; supervision, J.K.; project administration, J.K.; funding acquisition, J.K. All authors have read and agreed to the published version of the manuscript.

Funding: This work was supported by the Nuclear Safety Research Program through the Korea Foundation of Nuclear Safety (KoFONS) using the financial resource granted by the Nuclear Safety and Security Commission (NSSC) of Korea (no. 2003015). This research was also supported by the 2021 Research Fund of the KEPCO International Nuclear Graduate School (KINGS), the Republic of Korea.

Institutional Review Board Statement: Not Applicable.

Informed Consent Statement: Not Applicable.

Data Availability Statement: The data that support the findings of this study are available on request from the corresponding author.

Conflicts of Interest: The authors declare no conflict of interest.

\section{References}

1. International Atomic Energy Agency, Management of NORM Residues-IAEA-TECDOC-1712; IAEA: Vienna, Austria, 2013.

2. Dwipayana, C.A.W.; Moersidik, S.S.; Pratama, M.A. Estimation radiation dose from operation of petroleum NORM waste disposal in landfill using TSD-DOSE. J. Phys. Conf. Ser. 2020, 1572, 012031. [CrossRef]

3. Jeong, J.; Ko, N.Y.; Cho, D.K.; Baik, M.H.; Yoon, K.H. Estimation of exposure doses for the safe. Radiat. Prot. Dosim. 2018, 181, 394-402. [CrossRef] [PubMed]

4. Jang, M.; Chung, K.H.; Lim, J.M.; Ji, Y.Y.; Kim, C.J.; Kang, M.J. Analysis and evaluation for consumer goods containing NORM in Korea. Appl. Radiat. Isot. 2017, 126, 293-295. [CrossRef] [PubMed]

5. International Atomic Energy Agency. Radiation Safety for Consumer Products; IAEA Safety Standard Series No: SSG-36; IAEA: Vienna, Austria, 2016.

6. United State Nuclear Regulatory Commission (US NRC). Disposals of Very Low-Level Waste Under; US NRC: Rockville, MA, USA, 2002; Volume 10.

7. Hui-Gyeong, K.; Sang-Wook, H.; Su-Ri, P.; Byung-Jick, K. Safety assessment on the incineration disposal of regulation exempt waste by RESRAD code. J. Radiol. Sci. Technol. 2018, 41, 67-73. [CrossRef] 
8. Mora, J.C.; Baeza, A.; Robles, B.; Sanz, J. Assessment for the management of NORM wastes in conventional hazardous and nonhazardous waste landfills. J. Hazard. Mater. 2016, 310, 161-169. [CrossRef] [PubMed]

9. Grupen, C. Radiation protection. In Handbook of Particle Detection and Imaging; Springer: Berlin/Heidelberg, Germany, 2012; pp. 203-235. [CrossRef]

10. Yoon, S.-J. South Korea's experience with smart infrastructure services: Integrated solid waste management. Inter-Am. Dev. Bank 2020, 4, 421-425.

11. Liu, A.; Ren, F.; Lin, W.Y.; Wang, J.Y. A Review of Municipal Solid Waste Environmental Standards with a focus on Incinerator Residues. Int. J. Sustain. Built Environ. 2015, 4, 165-188. [CrossRef]

12. Harto, C.B.; Smith, K.P.; Kamboj, S.; Quinn, J.H. Radiological dose and risk assessment of landfill disposal of technologically enhanced naturally occurring radioactive materials (TENORM) in north Dakota. Argonne Natl. Lab. 2014. [CrossRef]

13. Njinga, R.L.; Tshivhase, V.M. Use of RESRAD-Onsite 7.2 code to assess environmental risk around tudor shaft mine tailing sites. Environ. Nat. Resour. Res. 2018, 8, 138-147. [CrossRef]

14. Ziajahromi, S.; Khanizadeh, M.; Nejadkoorki, F. Using the RESRAD code to assess human exposure risk to 226Ra, 232th, and 40K in Soil. Hum. Ecol. Risk Assess. 2015, 21, 250-264. [CrossRef]

15. Kontol, K.M.; Ahmad SH, S.S.; Omar, M. Radiological Impact Assessment for Landfill Disposal of NORM Wastes in Malaysia; Malaysian Nuclear Agency (Nuclear Malaysia): Bangi, Malaysia, 2007; pp. 355-359.

16. Oh, D.-Y.; Shin, K.-J.; Jeon, J.-S. Measurement and spatial analysis of Uranium-238 and Radon-222 of soil in Seoul. J. Soil Groundw Environ. 2017, 22, 33-40. [CrossRef]

17. Mujuni, R. Estimation of Radiological Impact from Uranium Mining and Milling Operations at Mkuju River Project in Tanzania; KINGS: Ulsan, Korea, 2020.

18. Faisalabad, R.C. Modeling Radiation Doses for a Hypothetical Contaminated Site Using RESRAD-OFFSITE Code Faisalabad, Haripur University, Haripur, Pakistan; Haripur University: Haripur, Pakistan, 2018.

19. Mathuthu, M.; Kamunda, C.; Madhuku, M. Modelling of radiological health risks from gold mine tailings in Wonderfonteinspruit catchment area, South Africa. Int. J. Environ. Res. Public Health 2016, 13, 570. [CrossRef] [PubMed]

20. Adliene, D.; Skridaila, N.; Motiejunas, S.; Meurville, C. Modelling of Carbon-14, Iodine-129 and Cesium-137 releases from near surface radioactive waste disposal and their impact on environment and humans. Kerntechnik 2007, 72, 268-273. [CrossRef]

21. ICRP. International Commission on Radiological Protection; Recommendations of the Radiological Protection Publication 26; ICRP: New York, NY, USA, 1977; Volume 26, pp. 1-87.

22. Radiation, M. Annals of the ICRP Annals of the ICRP Members of the Main Commission of the ICRP; ICRP: New York, NY, USA, 2000; Volume 30.

23. Sowby, F.D. Annals of the ICRP. Ann. ICRP 1981, 6, 1-2. [CrossRef]

24. Yu, C.; Zielen, A.J.; Cheng, J.J.; LePoire, D.J.; Gnanapragasam, E.; Kamboj, S.; Arnish, J.; Wallo, A., III; Williams, W.A.; Peterson, H. User's Manual for RESRAD Version 6. 2001. Available online: https:/ /resrad.evs.anl.gov/docs/resrad6.pdf (accessed on 5 July 2021).

25. Yu, C. User's Manual for Resrad-Offsite Code Version 4; Argonne National Laboratory Lemont: Lemont, IL, USA, 2020 ; Volume 4.

26. Edson, R.A.; Nelson, M.A.; Joao, B.T.R.; Ivana, B.M.C.; Liliane, F.B.; Greice, F.S.; Michel, M.M.; Veronica, V.R. HotSpot Health Physics Codes used as A Tool for Managing Excess Risk on Radiological Emergencies. pp. 1-7. Available online: https: / / inis.iaea.org/search/search.aspx?orig_q=RN:43052715 (accessed on 5 July 2021).

27. Avila, R.; Johansson, E.; Bugai, D.; Koliabina, D.; Falicia, A.B. User's Manual for NORMALYSA v. 2. 1 Mathematical Models and Parameters. 2018. Available online: https://www.researchgate.net/publication/326111484_User \T1 \textquoterights_manual_ for_NORMALYSA_v21_Description_of_Program_Module_Libraries_Mathematical_Models_and_Parameters (accessed on 5 July 2021).

28. Bugai, D.A.; Avila, R. Radionuclide Transport and Dose Calculations for Zapadnoe Uranium Mill Tailings Test Case Using NORMALYSA Tool. 2016. Available online: https://www.researchgate.net/publication/290448866__Radionuclide_transport_and_ dose_calculations_for_Zapadnoe_uranium_mill_tailings_test_case_using_NORMALYSA_tool (accessed on 5 July 2021). 